Nevşehir Bilim ve Teknoloji Dergisi Cilt 6(2) 643-660 2017

DOI: 10.17100/nevbiltek.305577

URL: http://dx.doi.org/10.17100/nevbiltek.305577

\title{
Türkiye'de İnşaat Sanayi Sektörünün Gelişimi-Temel İnşaat Sanayi Göstergeleri
}

\author{
Erdem KOÇ ${ }^{1}$, Kadir KAYA ${ }^{2}$, Mahmut Can ŞENEL ${ }^{1, *}$ \\ ${ }^{1}$ Ondokuz Mayıs Üniversitesi, Mühendislik Fakültesi, Makina Mühendisliği Bölümü, Samsun \\ ${ }^{2}$ Ondokuz Mayıs Üniversitesi, Fen Bilimleri Enstitüsü, Makina Mühendisliği Anabilim Dalı, Samsun \\ $\ddot{\mathbf{O z}}$
}

İnşaat sektörü, yarattığı katma değer ve istihdam açısından ülke ekonomilerinin en dinamik sektörüdür. Büyük ölçüde yerli sermayeye dayanan inşaat sektörü yüzlerce meslek dalını ilgilendirmekte olup istihdam ve üretim sürecini olumlu yönde etkilemektedir. Ülkemiz inşaat sektörünün dönemler ve yıllar içerisindeki gelişimini incelemek amacıyla çeşitli endeksler mevcuttur. Bu endeksler, İnşaat Ciro Endeksi, İnşaat Üretim Endeksi, İnşaat İşgücü Girdi Endeksleri ve İnşaat Malzemeleri Sanayi Bileşik Endeksi şeklinde sıralanabilir. Bu çalışmada, bahsedilen endekslerin yıllar içerisindeki değişimi incelenerek ülkemiz inşaat sektörünün genel durumu değerlendirilmiştir. Yürütülen çalışma neticesinde, ülkemiz inşaat sektörünün hem üretim hacmi hem de ciro bakımından her yıl büyümesine rağmen sektöre olan güven ve beklentinin oldukça düşük seviyede olduğu sonucuna varılmıştır.

Anahtar Kelimeler: İnşaat sektörü, inşaat ciro endeksi, inşaat üretim endeksi

\section{The Development of Construction Industry Sector in Turkey-Construction Industry Indicators}

\begin{abstract}
The construction sector is the most dynamic sector of the country's economy in terms of value added and employment created. Construction sector which is based on domestic capital to a large extent concerns hundreds of professions. Also, construction sector affects employment and production process positively. There are various indices to examine the developments of our country's construction industry over the years. These indices are Construction Turnover Index, Construction Production Index, Construction Labor Force Input Indices and Compound Index of Construction Material Industry. In this study, the general status of our country's construction sector was evaluated by examining the changes in these indices over the years. As a result of this study, it was concluded that the construction sector of our country grew year by year both in terms of production volume and turnover, whereas the confidence and expectation were found to be at very low level in the construction sector.
\end{abstract}

Keywords: Construction sector, construction turnover index, construction production index.

\footnotetext{
*e-mail: $\underline{\text { mahmutcan.senel@omu.edu.tr }}$
} 
1. Giriş

İnşaat sektörü; yoğun işgücü kullanımı, sosyo-ekonomik refah düzeyine olan katkısı ve yüzlerce çeşit mal-hizmet üretimiyle doğrudan bağlantılı olması sebebiyle ekonomik yapı içerisinde önemli bir yere sahiptir. Ayrıca yarattığı katma değer ve istihdam açısından ülke ekonomilerinin lokomotifi konumundadır. Büyük ölçüde yerli sermayeye dayanan Türkiye inşaat sektörü yüzlerce meslek dalını ilgilendirmekte olup istihdam ve üretim sürecini olumlu yönde etkilemektedir [1]

Ulusal ve uluslararası alanda büyük bir deneyime ve potansiyele sahip olan inşaat sektörü, kendisine bağlı 200'den fazla alt sektörü harekete geçirme özelliğiyle lokomotif sektör olarak adlandırılmaktadır. İnşaat sektörü, bina ve altyapı yatırımları olmak üzere ikiye ayrılmakta olup bina yatırımları ise konut ve konut dışı bina yatırımlardan oluşmaktadır [1].

İnşaat; topluma fayda sağlayan her türlü yeraltı ve yer üstü yapıları kapsayan çok geniş bir hizmet alt sektörü olarak da değerlendirilmektedir. İnşaat sanayi ile konut sahipliği, ulusal gelir hesaplamasında (Gayri Safi Milli Hasıla (GSMH) hesabı) üretim kolları, katma değerlerine göre dikkate alındığından (tarım, sanayi, inşaat sanayii, toptan ve perakende ticaret, ulaştırma ve haberleşme, mali müesseseler, konut sahipliği, serbest meslek ve hizmetler, banka hizmetleri gibi) iki ayrı üretim kolu veya sektör gibi ayrıma tabi tutulmaktadır. İnşaat sektörü içinde konut kapsamına her türlü konut inşaatı, ev ve apartman girmektedir. Türkiye'de sabit sermaye yatırımları içinde genelde birinci sırayı (yaklaşık \% 40) inşaat yatırımları almaktadır [2].

İnşaat sektörünün Gayri Safi Yurtiçi Hâsıla (GSYIH) içindeki payı yıllara göre değişim göstermektedir (Tablo 1). Farklı sektörlerin, seçilmiş dönemlerde GSYIH içindeki payları incelendiğinde 2002 yılında tarım $\% 13,8$, sanayi $\% 29,4$, inşaat $\% 4,6$, hizmetler $\% 52,2$ iken; 2015 y1lında tarım $\% 6$, sanayi $\% 28,4$, inşaat $\% 5,8$ ve hizmetler $\% 59,8$ 'dir. Bu süreçte tarım ve sanayi sektörlerinin GSYIH içindeki payı azalırken; inşaat ve hizmet sektörlerinin GSYIH içindeki payı artmıştır [1, 3-5].

Tablo 1. Seçilmiş yıllarda GSYIHH içinde sektörlerin payları [1, 3-5]

\begin{tabular}{ccccc}
\hline Yıl & Tarım (\%) & Sanayi (\%) & İnşaat (\%) & Hizmetler (\%) \\
$\mathbf{2 0 0 2}$ & 13,8 & 29,4 & 4,6 & 52,2 \\
$\mathbf{2 0 0 5}$ & 11,5 & 29,4 & 4,2 & 54,9 \\
$\mathbf{2 0 1 4}$ & 6,0 & 28,3 & 6,0 & 59,8 \\
$\mathbf{2 0 1 5}$ & 6,0 & 28,4 & 5,8 & 59,8 \\
\hline
\end{tabular}

Ülkemiz inşaat sektörünün dönemler/çeyrekler ve yıllar içerisindeki gelişimini takip etmek amacıyla çeşitli endeksler mevcuttur. Bu endeksler; İnşaat Ciro Endeksi, İnşaat Üretim Endeksi, İnşaat İşgücü Girdi Endeksleri ve İnşaat Malzemeleri Sanayi Bileşik Endeksi şeklinde sıralanabilir. $\mathrm{Bu}$ çalışmada, bu bahsedilen endekslerin yıllar içerisindeki değişimi incelenerek ülkemiz inşaat sektörünün genel durumu değerlendirilmiştir.

\section{2. İnşaat Sektörü ve Endeksler}

\section{1. İnşaat Tipleri}

İnşaat sektörünün genel durumunu değerlendirmek amacıyla İnşaat Ciro Endeksi, İnşaat Üretim Endeksi, İnşaat İşgücü Girdi Endeksi ve İnşaat Malzemeleri Sanayi Bileşik Endeksi gibi endeksler kullanılmaktadır. Bu endeksler, Avrupa Topluluğu Ekonomik Faaliyet Sınıflaması (NACE Rev.2) ve 
İnşaat Tipleri Sınıflamasına (ITS) göre hesaplanmakta olup bu sınıflamalara göre inşaat sektöründe kapsanan alt sektörler aşağıda verilmiştir [6].

- Avrupa Topluluğu Ekonomik Faaliyet Sınıflaması'na (NACE Rev.2) göre İnşaat Sektörü

○ Bina İnşaatı

- İkamet amaçlı olan veya ikamet amaçlı olmayan binaların inşaatı

- Bina Dışı Yapıların İnşaatı

- Kara ve demir yollarının inşaatı

- Hizmet projelerinin inşaatı

- Bina dışı diğer yapılara ait projelerin inşaatı

○ Özel İnşaat Faaliyetleri

- Yıkım ve şantiyenin hazırlanması

- Elektrik tesisatı, sıhhi tesisat ve diğer inşaat tesisatı faaliyetleri

- Yapının tamamlanması ve bitirilmesi

- Diğer özel inşaat faaliyetleri

- İnşaat Tipleri Sınıflaması'na (İTS) göre İnşaat Sektörü

○ Bina İnşaat

○ Bina Dışı İnşaat

NACE Rev. 2 sınıflandırmasına göre Bina İnşaatı, Bina Dışı Yapıların İnşaatı ve Özel İnşaat Faaliyetleri olarak üçe ayrılmaktadır. [6].

- Bina İnşaatı: Konutların, ofis binalarının, işyerlerinin, dükkânların özel ve kamu kurumu binalarının, çiftlik binaları ve benzeri binaların komple inşaatıdır.

- Bina Dışı Yapıların İnşaatı: Otoyollar, caddeler, köprüler, tüneller, demir yolları, havaalanları, limanlar, sanayi tesisleri, boru ve elektrik hatları, açık hava spor tesisleri gibi ağır inşaat faaliyetleridir.

- Özel İnşaat Faaliyetleri: Özel uzmanlık gerektiren inşaat faaliyetleri, inşaat ince işleri ve diğer tamamlama faaliyetleri, her türlü tesisat işleri, asansör ve yürüyen merdivenlerin kurulumu, yollar, demiryolu ve diğer raylı yollar, sıvama, boyama, doğramacılık, dış cephe temizlemesi gibi inşaatın tamamlanmasına yardımcı olan faaliyetlerdir.

İnşaat Tipleri Sınıflaması'na (ITS) göre Bina İnşaatı ve Bina Dışı İnşaat kategorileri ise aşağıdaki gibi değerlendirilmektedir [6].

- Bina İnşaatı: Bina inşaat ile ikamet amaçlı kullanılan binaların, konut birimiyle direk bağlantılı olarak kullanılan garajların, ek binaların ve diğer küçük binaların, tarımsal amaçlı binaların; ofiss, alışveriş ve ticari binaların, okul binalarının, kütüphane binalarının, müzelerin, hastanelerin, hapishanelerin, karakolların, su depolarının, dini binaların, sanayi binalarının (kimyasal fabrikalar hariç), tren istasyonlarının, otobüs terminalleri vb. ulaşım ile ilgili binaların inşaatı değerlendirilmektedir.

- Bina Dışı İnşaat: Bina dışı inşaat ile şehirlerarası ve şehir içi yollar, karayolları, sokaklar, yaya yolları, köprüler, otoyollar, havaalanı yolları, demiryolu ve diğer raylı yollar, barajlar, tüneller ve yeraltı yolları, limanlar, su kanalları, iskele, bent, tersaneler, gaz ve petrol boru hatları, su boru hatları; kanalizasyon veya yağmur suyu için boru hatları, demiryolu ve diğer raylı yollar için elektrik güç hatları, enerji hatları, iletişim hatları, haberleşme nakil hatları, enerji santralleri, kimyasal fabrikalar, rafineriler, spor alanları, eğlence parkları, hayvanat bahçeleri vb. inşaatlar değerlendirilmektedir. 


\section{2. İnşaat Ciro Endeksi}

İnşaat Ciro Endeksi (ICE), belirli bir dönem veya yıl boyunca inşat sektöründeki toplam hasılatın artış veya azalışını takip etmek ve karşılaştırmak amacıyla kullanılan bir endeks türüdür. İCE, sabit temel yıl (2010=100 gibi) ağırlıklı hesaplanmaktadır. Sabit fiyatlarla gayri safi yurtiçi hasıla inşaat sektörü üretim verilerinden yararlanılarak belirlenen verimlilik katsayısıyla çalışılan saat endeksi düzeltilerek ise İnşaat Üretim Endeksi (İÜE) belirlenmektedir. İnşaat Ciro Endeksi ağırlıkları için 2010 yıllık Sanayi ve Hizmet İstatistikleri sonuçları; İnşaat Üretim Endeksi ağırlıkları için ise Gayri Safi Yurtiçi Hâsıla (GSYIH) inşaat sektörü verileri kullanılmaktadır.

İnşaat Ciro ve Üretim Endeksleri'nin hesaplanmasında esas olan anket verileri, İnşaat Sektörü Üç Aylık Soru Formu'nun doğrudan seçilen işyerlerince elektronik ortamda doldurulmasıyla elde edilmektedir. Alan çalışması veya anket, 20 ve üzerinde çalışanı bulunan işyerleri veya girişimlerde, her ilde o ilin bağlı olduğu Türkiye İstatistik Kurumu (TÜİK) Bölge Müdürlüğü’nce yapılmaktadır [6].

Mevsim ve takvimden kaynaklanan etkiler, geçici nitelikte olduklarından, verinin genel eğiliminin gözlemlenmesini engellemektedir. Mevsimsel hareketler içeren veride, belirli bir dönemde meydana gelen değişikliğin, verideki gerçek artış veya azalıştan mı, yoksa mevsimsel etkilerden mi kaynaklandığını anlamak oldukça güçtür. Kısa dönemli göstergelerde aylık/dönemlik ve yıllık değişimlerin sağlıklı bir şekilde yorumlanabilmesi için, bir önceki aya/döneme göre yapılacak karşılaştırmalarda Mevsim ve Takvim Etkilerinden Arındırılmış göstergelerin kullanılması; bir önceki yılın aynı ayına/dönemine göre yapılacak karşılaştırmalarda ise Takvim Etkisinden Arındırılmış göstergelerin kullanılması verilerin daha sağlıklı yorumlanmasını sağlayacaktır.

\section{3. İnşaat Üretim Endeksi}

İnşaat Üretim Endeksi (iÜE), belirli bir dönem veya yıl içerisinde inşaat sektöründeki üretim artışııı/azalışını takip etmek ve karşılaştırmak amacıyla kullanılan bir göstergedir. İÜE, havaların ısındığı ve bu nedenle inşaatların arttı̆̆ı bahar ve yaz dönemlerinde artış gösterirken, soğuk ve yağışlı kış döneminde azalmaktadır. İnşaat Ciro Endeksi ise muhasebeleştirme işlemlerinin yıl sonuna sarkması nedeniyle genellikle 4. çeyrekte artarken, 1. çeyrekte azalmaktadır. Dolayısıyla İnşaat Ciro ve Üretim Endekslerinde mevsim ve takvim etkileri bulunduğundan söz konusu veriler Takvim Etkisinden Arındırılmış, Mevsim ve Takvim Etkisinden Arındırılmış olarak da yayınlanmaktadır [3].

Arındırılmamış veriden, takvim ve tatilden kaynaklanan etkiler arındıııldığında, Takvim Etkisinden Arındırılmış veri elde edilmekte olup bu veriler bir önceki yılın aynı ayına/dönemine göre yapılan karşılaştırmalarda kullanılmaktadır. Arındırılmamış veriden, hem mevsim hem de takvim ve tatil etkileri arındırıldığında, Mevsim ve Takvim Etkisinden Arındırılmış veri elde edilmekte olup bu veriler bir önceki aya/döneme göre yapılan karşılaştırmalarda kullanılmaktadır [6].

\section{4. İnşaat İşgücü Girdi Endeksleri}

İnşaat sektöründeki; istihdam, çalışılan saat ve brüt ücret-maaş gibi bilgiler elde edilerek sektörün zaman içindeki gelişiminin, dönemler/çeyrekler ve yıllar içindeki değişiminin izlenebilmesi amacıyla İnşaat İşgücü Girdi Endeksleri elde edilmektedir. İnşaat İşgücü Girdi Endeksleri Avrupa Topluluğu Ekonomik Faaliyet Sınıflaması ve İnşaat Tipleri Sınıflamasına göre hesaplanmakta olup yapılan sınıflandırmalarda değerlendirilen kategoriler daha önce verilen İCE ve İÜE ile aynıdır. 
İnşaat İşgücü Girdi Endeksi, sabit temel yıl (2010=100 gibi) ağırlıklı olarak İnşaat Ciro ve Üretim Endeksleri ile benzer şekilde hesaplanmaktadır. Bu endekslerin ağırlıkları için de 2010 yıllık Sanayi ve Hizmet İstatistikleri sonuçları kullanılmaktadır. İnşaat İşgücü Girdi Endeksleri’nin hesaplanmasında esas olan anket verileri, İnşaat Sektörü Üç Aylık Soru Formu'nun doğrudan seçilen işyerlerince elektronik ortamda doldurulmasıyla elde edilmektedir. Alan çalışması veya anket, 20 ve üzerinde çalışanı bulunan işyerleri veya girişimlerde, her ilde o ilin bağlı olduğu Türkiye İstatistik Kurumu (TÜiK) Bölge Müdürlüğü’nce yapılmaktadır [7].

İnşaat İşgücü Girdi Endeksleri de İnşaat Üretim Endeksleri’nde olduğu gibi havaların 1sındığı ve bu nedenle inşaatların arttığı bahar ve yaz dönemlerinde artış gösterirken, soğuk ve yağışlı kış dönemlerinde azalmaktadır. İnşaat İşgücü Girdi Endeksleri'nde mevsim ve takvim etkileri bulunduğundan söz konusu veriler Takvim Etkisinden Arındırılmış ve Mevsim ve Takvim Etkisinden Arındırılmış olarak da yayımlanmaktadır [3].

İnşaat İşgücü Girdi Endeksleri; İnşaat İstihdam Endeksi (iïE), İnşaat Çalışılan Saat Endeksi (İÇSE) ve İnşaat Brüt Ücret-Maaş Endeksi'nden (İBÜME) meydana gelmektedir. Bu endekslerin y1llar ve dönemler içerisindeki değişimi bir sonraki bölümde detaylı incelenecektir [7].

\section{5. İnşaat Malzemeleri Sanayi Bileşik Endeksi}

İnşaat Malzemeleri Sanayi (IMS) Bileşik Endeksi, inşaat malzemeleri sanayinde ölçülen faaliyet, güven ve beklentilerin bileşimi ile oluşturulan ve inşaat sanayinin genel durumunu ortaya koyan bir endekstir. Bu endeks aylık olarak yayınlanmakta olup Türkiye İnşaat Malzemeleri Sanayicileri Derneği (Türkiye İMSAD) tarafindan düzenlenmektedir $[8,9]$.

Bu endeks; Türkiye ekonomisinde ve imalat sanayinde üretim, yatırım, istihdam ve ihracat alanlarında çok önemli bir pay alan inşaat malzemeleri sanayii için aşağıdaki amaçlarla belirlenmektedir [8].

- Gelişmelerin ve beklentilerin yakından izlenmesi,

- Gelişme ve beklentilerin endeks veya sayısal hale getirilmesi,

- Gelişme ve beklentilerin önce sektör temsilcileri, sonrasında ise sektörün tüm paydaşları ve ekonomi yönetimiyle ve son olarak kamuoyu ile paylaşı1ması,

- Sektörün içindeki ve dışındaki tüm aktörler için yol gösterici nitelikte, sürekli ve düzenli bir bilgi seti oluşturulmasıdır.

İnşaat Malzemeleri Sanayi Bileşik Endeksi; İnşaat Malzemeleri Sanayi Faaliyet Endeksi, İnşaat Malzemeleri Sanayi Güven Endeksi ve İnşaat Malzemeleri Sanayi Beklenti Endeksi gibi ana alt endekslerin birleşiminden elde edilmektedir.

Ana alt endekslerden, İnşaat Malzemeleri Sanayi Faaliyet Endeksi, inşaat malzemeleri sanayiinde faaliyet gösteren firmaların faaliyet seviyesini; İnşaat Malzemeleri Sanayi Güven Endeksi, inşaat malzemeleri sanayinde faaliyet gösteren firmaların ekonomi ve sektöre yönelik duydukları güven seviyesini; İnşaat Malzemeleri Sanayi Beklenti Endeksi, inşaat malzemeleri sanayiinde faaliyetlerin gelecek üç aylık dönemde hangi seviyede olacağına ilişkin beklentileri tespit eden bir endekstir [9].

İnşaat Malzemeleri Sanayi (IMS) Faaliyet Endeksi, Yurtiçi Satış Endeksi, Üretim Endeksi, İhracat Endeksi, Ciro Endeksi, Tahsilat Hızı Endeksi, Yurtdışı Satış Fiyatları Endeksi gibi alt endekslerin birleşiminden elde edilmektedir. 
İnşaat Malzemeleri Sanayi (IMSS) Güven Endeksi, Türkiye Ekonomisi Genel Gidişat Endeksi, İnşaat Sektörü Genel Gidişat Endeksi, İnşaat Malzemeleri Sanayi Genel Gidişat Endeksi, Yurtiçi Pazarlar Genel Gidişat Endeksi, İnşaat Pazarları Genel Gidişat Endeksi gibi alt endekslerin birleşiminden elde edilmektedir.

İnşaat Malzemeleri Sanayi (IMS) Beklenti Endeksi, Türkiye Ekonomisine İlişkin Üç Aylık Beklenti Endeksi, İnşaat Malzemesi Sanayine İlişkin Üç Aylık Beklenti Endeksi, Önümüzdeki Üç Aya İlişkin Alınan Yurtiçi Siparişler Endeksi, Önümüzdeki Üç Aya İlişkin İhracat Siparişleri Endeksi, Önümüzdeki Üç Aya İlişkin Üretim Beklentisi Endeksi, Önümüzdeki Üç Aya İlişkin Yatırım Beklentisi Endeksi gibi alt endekslerin birleşiminden elde edilmektedir [10].

İnşaat Malzemeleri Sanayi (IMS) Bileşik Endeksi ve alt endeksleri, önceden belirlenen firmalarla yapılan anket çalışmaları ile elde edilmekte olup anket yapılan firmalar sektör genelini önemli ölçüde yansıtan 22 alt sektörden seçilen 100 firmadır. Anket kapsamında ise belirlenen firmalara her bir alt endeks için farklı sorular sorulmakta olup katılımcılardan sorulara arttı, azaldı, aynı kaldı/değişmedi, artacak, azalacak, daha iyimserim, daha kötümserim şeklinde cevaplaması istenmektedir. Sorulara verilen cevaplar içinden aynı kaldı veya değişmedi yanıtları çıkarılmakta, arttı ile azaldı, artacak ile azalacak ve daha iyimserim ile daha kötümserim şeklindeki cevapların sayısal farkları 10'a bölünerek 100'e eklenmekte ve endeks değeri elde edilmektedir. Bu hesaplamada kullanılan 100 değeri endeksin ilk hesaplandığı ayda (2013 Eylül) kullanılan temel endeks değeridir (2013 Ağustos=100).

Alt endeksler için, sorulan sorular sanayi için taşıdıkları önem ağırlıklarına göre ağırlıklandırılmakta, ağılık puanları toplanarak her ay için alt endeks değerleri hesaplanmaktadır. Üç alt endeks değerinin ağırlıklandırılması sonucunda da IMSS Bileşik Endeksi elde edilmektedir.

İMS Bileşik Endeksi'nin hesaplanmasında kullanılan anketler bir önceki ay hakkındaki değerlendirmeler ve gelecek üç aya ait beklentileri içermekte olup anketler her ayın ilk 10 günü içerisinde yapılmakta, anket sonuçlarını ifade eden endeksler ayın 12-15'inde açıklanmaktadır.

\section{Genel Değerlendirme ve İrdeleme}

Bu bölümde, bir önceki bölümde tanımlanan İnşaat Ciro Endeksi, İnşaat Üretim Endeksi, İnşaat İşgücü Girdi Endeksleri ve İnşaat Malzemeleri Sanayi Bileşik Endeksi gibi endekslerin ülkemizde dönemler/çeyrekler ve yıllar içerisindeki değiş̧imi değerlendirilmiştir.

\section{1. İnşaat Ciro ve İnşaat Üretim Endekslerinin Durumu}

İnşaat tipleri sınıflaması (İTS)'na göre İnşaat Ciro Endeksi'nin 2013-2016 yıllarında çeyrekler bazında değişimi Tablo 2'de verilmiştir. Tabloda İnşaat Ciro Endeksi'ne ek olarak İTS'ye göre Bina ve Bina Dışı için İnşaat Ciro Endeksleri ve söz konusu endekslerin yıllık ortalama değerleri de verilmektedir. 2016 yılı esas alındığında Bina Ciro Endeksi değerlerinin Toplam İnşaat Ciro Endeksi ve Bina Dışı İnşaat Ciro Endeksi değerlerinden daha yüksek olduğu görülmektedir. Toplam İnşaat Ciro Endeksi, Bina İnşaat Ciro Endeksi ve Bina Dışı İnşaat Ciro Endeksi değerlerinin 2016 yılı ortalaması sirasıyla 148,1, 158,9 ve 131,4 değerlerini aldığı da tablodan izlenebilmektedir. 2016 y1lının tüm çeyreklerinde toplam inşaat ciro endeksi değerleri yaklaşık 100 ve üzerinde seyrettiğinden bu durum inşaat sektörünün yıllık ciro bakımından iyi bir yıl geçirdiğini göstermektedir. 
Tablo 2. 2013-2016 yıllarında İTS'ye göre inșaat ciro endeksi değișimi $[6,11]$

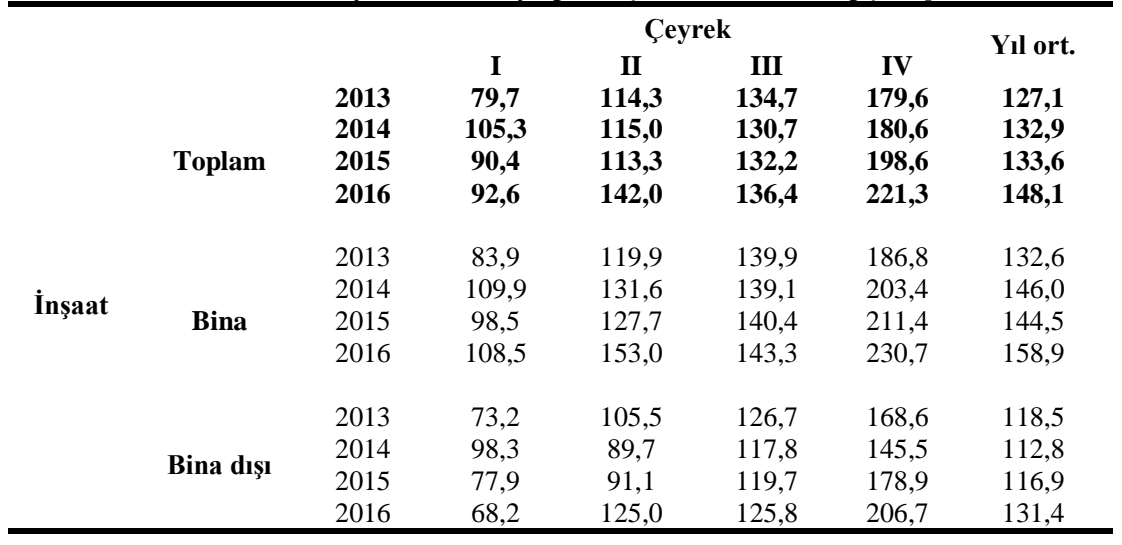

İnşaat tipleri sınıflaması (İTS)'na göre İnşaat Üretim Endeksi'nin 2013-2016 y1llarında çeyrekler bazında değişimi Tablo 3'de verilmiştir. Tabloda İnşaat Üretim Endeksi'ne ek olarak İTS'ye göre Bina ve Bina Dışı için İnşaat Üretim Endeksleri ve söz konusu endekslerin yıllık ortalama değerleri de verilmektedir. 2016 yılı esas alındığında Bina Üretim Endeksi değerlerinin Toplam İnşaat Üretim Endeksi ve Bina Dışı İnşaat Üretim Endeksi değerlerinden yüksek olduğu görülmektedir. Toplam İnşaat Üretim Endeksi, Bina İnşaat Üretim Endeksi ve Bina Dışı İnşaat Üretim Endeksi değerlerinin 2016 yılı ortalaması sırasıyla 130,5, 132,2 ve 124,7 değerlerini aldığı da görülmüştür. Genel olarak 2016 yılı İnşaat Üretim Endeksinin ülkemizdeki durumu değerlendirildiğinde; bu endeksin 100 endeks değerinin oldukça üzerinde olduğu görülmüştür. Bu durum, 2016 yılında inşaat sektöründe üretim ve satış faaliyetlerinin oldukça canlı olduğunu göstermektedir.

Tablo 3. 2013-2016 yıllarında ITS'ye göre inşaat üretim endeksi değişimi [6, 12]

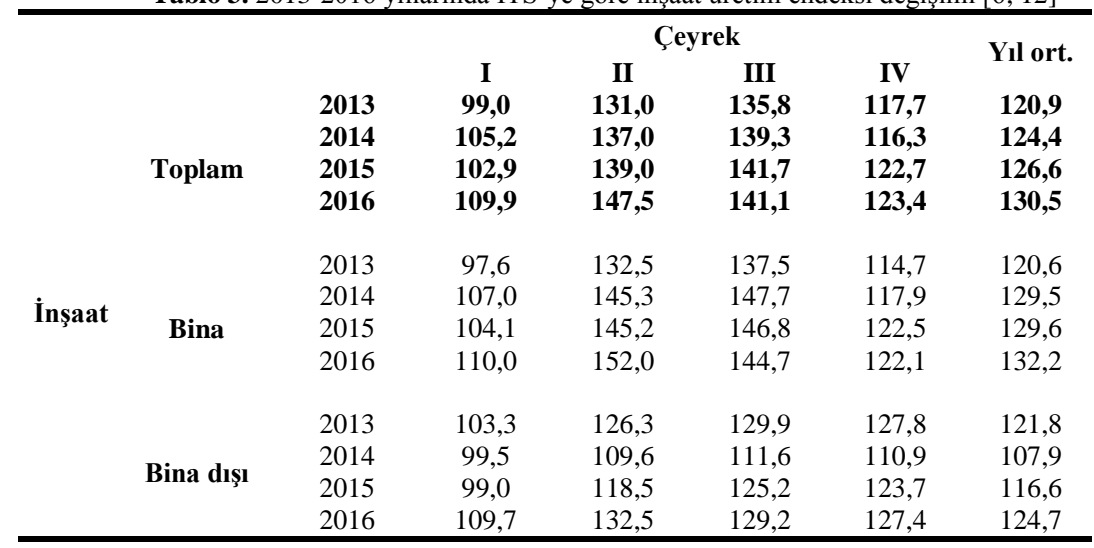

2015 y1lı ve 2016 yll ilk üç çeyreğinde İnşaat Ciro Endeksi (İCE) ve İnşaat Üretim Endeksi (IÜE)'nin çeyrekler bazında değişimi Şekil 1'de verilmiştir. İCE'nin 2015 yllında en düşük değerini I. çeyrekte $(90,4)$, en yüksek değerini ise IV. çeyrekte $(198,6)$ aldığı belirlenmiştir. İCE'nin 2016 yllı I. çeyreğinde 92,6, IV. çeyreğinde ise 221,3 değerlerini aldığı da şekilden izlenebilmektedir. 2016 y1lı II. çeyreğinde 142 değerini alan İCE'nin III. çeyrekte 136,4'e; benzer şekilde 2016 yllı II. çeyreğinde 147,5 değerini alan İÜE'nin ise 141,1'e gerilediği de tespit edilmiştir. Bu durum, ekonomik büyümeyle paralel olarak 2016 yılında 2015 yılına göre inşaat sektöründeki cironun (\%12) ve sektördeki üretim faaliyetlerinin $(\% 3,2)$ arttığını göstermektedir. 


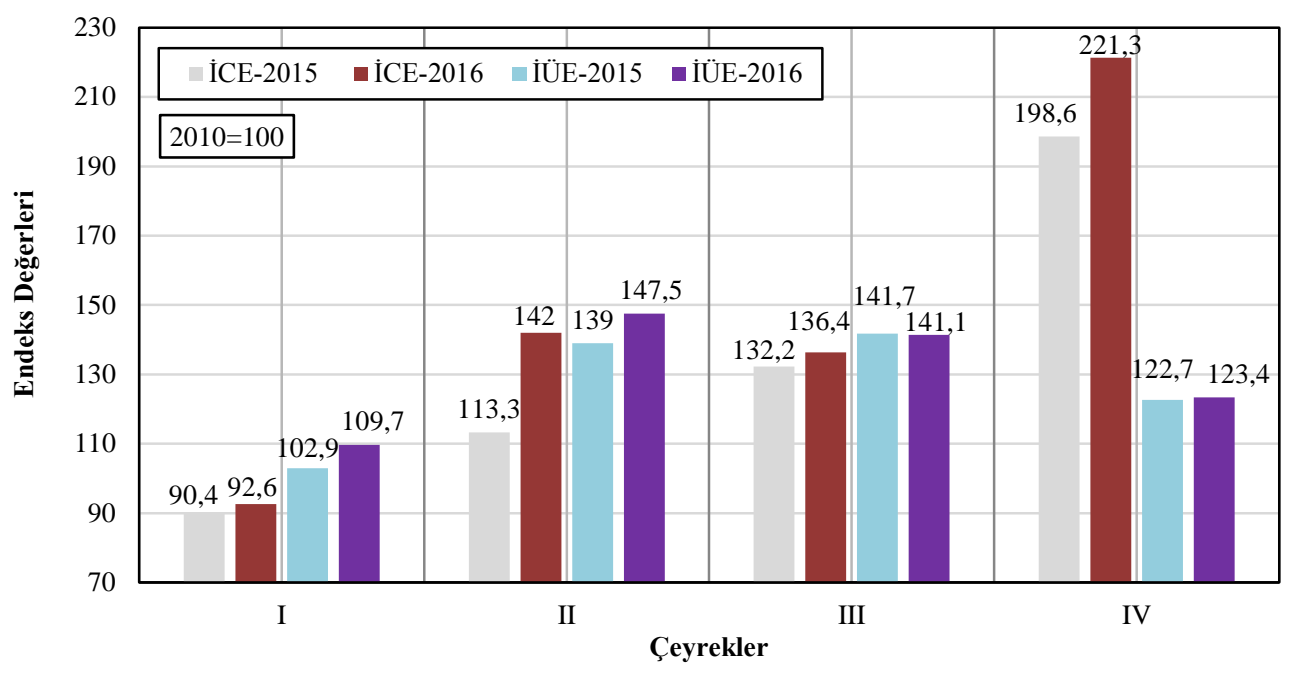

Şekil 1. 2015 ve 2016 yıllarında İCE ve İ̈E değişimi $[6,11]$

İnşaat Ciro Endeksi ve İnşaat Üretim Endeksi değerlerinin çeyrekler bazında değişimi Mevsim ve Takvim Etkilerinden Arındırılarak da yayınlanmaktadır. Bu kısımda söz konusu endeks değerlerinin değişimi tablolar şeklinde verilmemiş olup tablo değerlerinden elde edilen eğrilerden yararlanılarak değerlendirmeler yapılmıştır. 2013-2016 yılları için İnşaat Ciro Endeksi'nin \% değişimleri Şekil 2'de verilmiştir. Takvim Etkisinden Arındırılmış İnşaat Ciro Endeksi (İCETA)'nde en büyük artışın 2014 yılı I. çeyreğinde (\% 32,2); en büyük azalışın 2015 yılı I. çeyreğinde (\%-14,2) olduğu; Mevsim ve Takvim Etkileri Arındırıımış İnşaat Ciro Endeksi (İCE-MTA) değerleri esas alındığında en büyük artışın 2014 yılı I. çeyreğinde (\% 29,3); en büyük azalışı 2014 yılı II. çeyreğinde (\%-20,7) gerçekleştiği görülmektedir. 2016 yılı IV. çeyreğinde; İCE-TA'nın bir önceki yılın aynı çeyreğine göre \% 11,4 artarak 198,6'dan 221,3'e yükseldiği; İCE-MTA'nın ise bir önceki çeyreğe göre \% 5,4 artarak 144,9'dan 152,7'ye yükseldiği de şekilden izlenebilmektedir. Bu durum, mevsim ve takvim etkisinden arındırıldığı durumda inşaat sektöründeki cironun her yıl arttığını (yaklaşık \%10) ve ekonomik kalkınmadaki lokomotif sektör olduğunu göstermektedir.

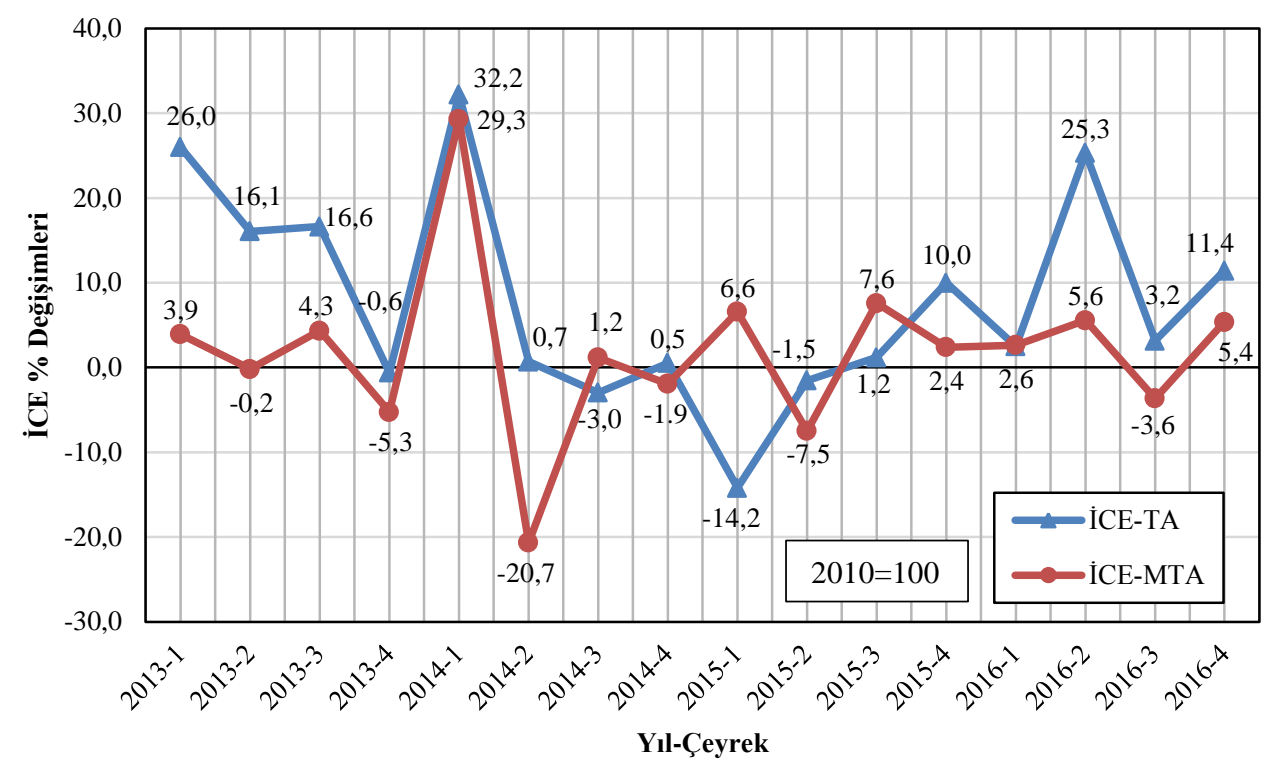

Şekil 2. 2013-2016 yıllarında İCE-TA ve İCE-MTA \% değişimleri [6, 11] 
2013-2016 yılları arasında İnşaat Üretim Endeksi'nin \% değişimleri Şekil 3'de verilmiştir. Şekilden Takvim Etkisinden Arındırılmış İnşaat Üretim Endeksi (iÜE-TA)'nde en büyük artışın 2013 yılı III. çeyreğinde (\% 8,7); en büyük azalışın 2015 yılı I. çeyreğinde (\% -2,2) olduğu; Mevsim ve Takvim Etkisinden Arındırıımış İnşaat Üretim Endeksi (IÜEE-MTA) değerleri esas alındığında en büyük artışın 2016 yılı I. çeyreğinde (\% 4,2); en büyük azalışın 2016 y1lı III. çeyreğinde (\%-4,9) gerçekleştiği görülmektedir. 2016 yılı IV. çeyreğinde; IÜE-TA'nın bir önceki yılın aynı çeyreğine göre \% 0,5 artarak 121,8'den 122,4'e yükseldiği; İÜE-MTA'nın ise bir önceki çeyreğe göre \% -1,4 azalarak 128,3'den 126,5'e gerilediği şekilden izlenebilmektedir. 2016 yllı 3.çeyreğinde gerçekleşen inşaat üretim endeksindeki bu düşüş, ülkemizde gerçekleşen darbe teşebbüsünün inşaat sektörünü son derece olumsuz etkilediğini de göstermektedir.

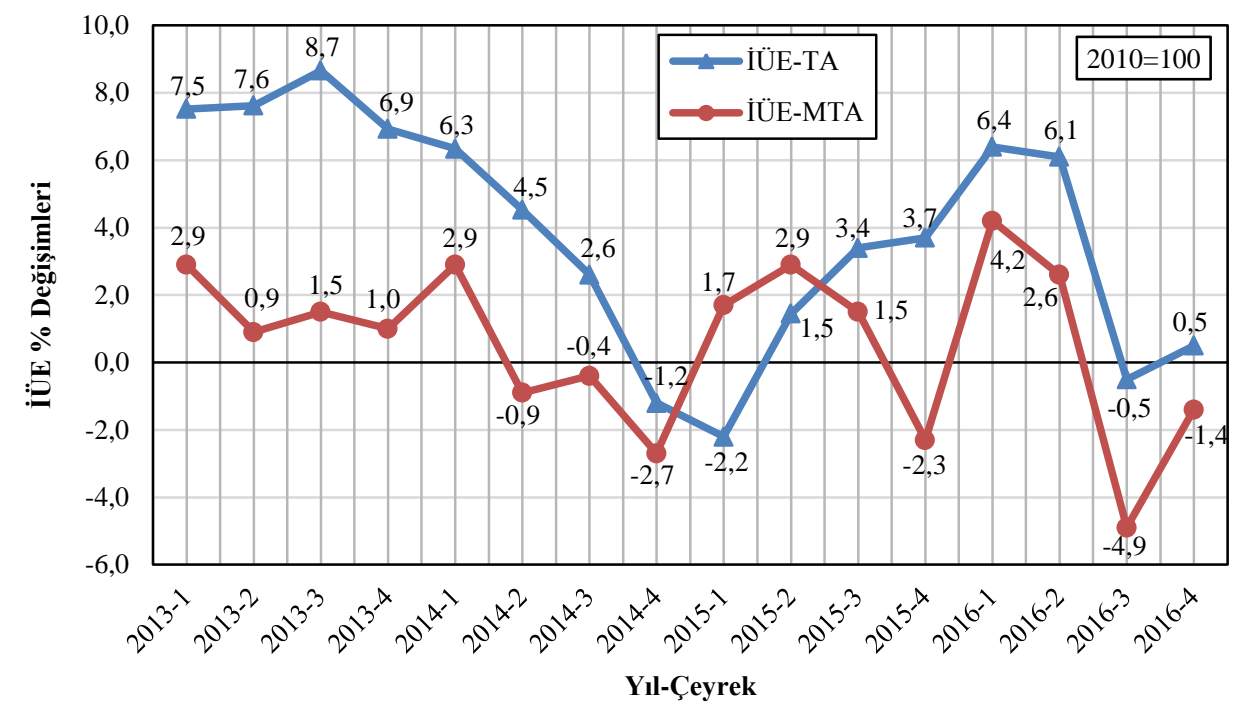

Şekil 3. 2013-2016 yıllarında Ï̈E-TA ve İ̈̈E-MTA \% değişimleri [6, 12]

Mevsim ve Takvim Etkisinden Arındırılmış İnşaat Ciro Endeksi (İCE-MTA) ve İnşaat Üretim Endekslerinin (iÜE-MTA) çeyrekler bazındaki \% değişimleri karşılaştırma amacıyla Tablo 4'de verilmiştir. Buradaki değerler daha önceden de izah edildiği gibi aynı yılın bir önceki dönem veya çeyreğine göre değişimin daha sağlkklı yorumlanmasını sağlayan mevsim ve takvim etkisinden arındırılmış değerlerdir. Tablodan İCE-MTA \% değişimlerinin IÜE-MTA \% değişimlerinden daha yüksek değerlerde olduğu görülmektedir. İCE-MTA \% değişiminde en büyük artışın 2014 yılı I. çeyreğinde (\% 29,3), en büyük azalışın ise 2014 yılı II. çeyreğinde (\% -20,7) olduğu; İÜE-MTA \% değişimlerinde ise en büyük artışı 2016 yılı I. çeyreğinde (\% 4,2), en büyük azalışın ise 2014 yılı IV. çeyreğinde (\% -2,7) olduğu da tablodan izlenebilmektedir.

İnşaat sektöründe Mevsim ve Takvim Etkisinden Arındırılmış İnşaat Ciro Endeksi'nin (İCEMTA) 2016 yılı son çeyreğinde bir önceki çeyreğe göre (2016 y1lı III. çeyreği) \% 9 arttığı, aynı şekilde Mevsim ve Takvim Etkisinden Arındırılmış İnşaat Üretim Endeksi’nin (IÜE-MTA) de bir önceki çeyreğe göre (2016 y1lı III. çeyreği) \% 3,8’ lik azalış gösterdiği gözlemlenmektedir. 
Tablo 4. 2014-2016 yıllarında İnşaat Ciro Endeksi ve İnşaat Üretim Endeksi \% değişimleri [11, 12]

\begin{tabular}{cccc}
\multicolumn{2}{c}{ Tablo 4. $2014-2016$ yillarında Inşaat Ciro Endeksi ve Inşaat Üretim Endeksi \% değişimleri $[11,12]$} \\
\hline \multirow{2}{*}{2014} & İCE-MTA Değişimi (\%) & İÜE-MTA Değişimi (\%) \\
\cline { 2 - 3 } 2015 & 29,3 & 2,9 \\
& I. Çeyrek & $-20,7$ & $-0,9$ \\
& II. Çeyrek & 1,2 & $-0,4$ \\
& III. Çeyrek & $-1,9$ & $-2,7$ \\
& IV. Çeyrek & & \\
& & 6,6 & 1,7 \\
& I. Çeyrek & $-7,5$ & 2,9 \\
& II. Çeyrek & 7,6 & 1,5 \\
& III. Çeyrek & 2,4 & $-2,3$ \\
& IV. Çeyrek & & 4,2 \\
& & 2,6 & 2,6 \\
& I. Çeyrek & 5,6 & 1,5 \\
& II. Çeyrek & $-3,6$ & $-2,3$ \\
\hline
\end{tabular}

\section{2. İnşaat İşgücü Girdi Endekslerinin Durumu}

İnşaat İşgücü Girdi Endeksleri; İnşaat İstihdam Endeksi (İIE), İnşaat Çalşşlan Saat Endeksi (İÇSE) ve İnşaat Brüt Ücret-Maaş Endeksi'nden (IBBÜME) meydana gelmektedir. İnşaat tipleri sınıflaması (ITS)'na göre İnşaat İstihdam Endeksi (ïIE)'nin 2013-2016 y1llarında çeyrekler bazında değişimi Tablo 5'de verilmiştir. 2010 referans yılında 100 olan İstihdam Endeksi en düşük değerlerini 2016 yllında almış yani 2016 yılında istihdam 2010 yılına göre en düşük seviyede gerçekleşmiştir. Toplam İnşaat İstihdam Endeksi, Bina İnşaat İstihdam Endeksi ve Bina Dışı İnşaat İstihdam Endeksi değerlerinin 2016 yılı ortalaması sırasıyla 73,9, 74,5 ve 72,6 değerlerini almıştır.

Tablo 5. 2013-2016 yıllarında İTS'ye göre İnşaat İstihdam Endeksi değişimi [7, 13]

\begin{tabular}{|c|c|c|c|c|c|c|c|}
\hline \multirow[b]{2}{*}{ Ekonomik faaliyet } & \multirow[b]{2}{*}{ İnşaat tipleri } & \multirow[b]{2}{*}{ Yıl } & \multicolumn{5}{|c|}{ İstihdam Endeksi } \\
\hline & & & I & II & III & IV & Yll ort. \\
\hline \multirow{12}{*}{ İnşaat } & \multirow{4}{*}{ Toplam } & 2013 & 94,1 & 100,7 & 101,1 & 97,9 & 98,5 \\
\hline & & 2014 & 88,3 & 89,9 & 86,1 & 84,5 & 87,2 \\
\hline & & 2015 & 77,4 & 81,9 & 81,0 & $\mathbf{7 9 , 5}$ & 79,9 \\
\hline & & 2016 & 72,5 & 75,7 & 75,3 & 72,3 & 73,9 \\
\hline & \multirow{6}{*}{ Bina } & 2013 & 97,4 & 102,3 & 101,1 & 98,9 & 99,9 \\
\hline & & 2014 & 91,7 & 93,0 & 88,4 & 87,8 & 90,2 \\
\hline & & 2015 & 82,8 & 85,7 & 83,0 & 82,2 & 83,4 \\
\hline & & 2016 & 76,3 & 77,2 & 74,3 & 70,3 & 74,5 \\
\hline & & 2013 & 86,7 & 97,2 & 101,2 & 95,8 & 95,2 \\
\hline & & 2014 & 80,4 & 82,8 & 81,0 & 76,9 & 80,3 \\
\hline & \multirow{2}{*}{ Bina dışı } & 2015 & 65,0 & 73,1 & 76,3 & 73,4 & 72,0 \\
\hline & & 2016 & 63,8 & 72,2 & 77,7 & 76,9 & 72,6 \\
\hline
\end{tabular}

İnşaat tipleri sınıflaması (ITTS)'na göre İnşaat Çalışılan Saat Endeksi (ICCSE)'nin 2013-2016 yıllarında çeyrekler bazında değişimi Tablo 6'da verilmiştir. İnşaat Çalışılan Saat Endeksi'ne ek olarak İTS'ye göre Bina ve Bina Dıı̧ı için İnşaat Çalışılan Saat Endeksleri ve söz konusu endekslerin yıllık ortalama değerleri de verilmektedir. 2010 referans yılında 100 olan endeksin en düşük değerlerini 2016 yılında aldığı, yani 2016 yılında inşaatta çalışılan saatlerin 2010 yılına göre en düşük seviyede gerçekleştiği görülmektedir. Toplam İnşaat Çalışılan Saat Endeksi, Bina İnşaat Çalışılan Saat Endeksi ve Bina Dışı İnşaat Çalışılan Saat Endeksi değerlerinin 2016 yılı ortalaması sırasıyla 69,5, 69,8 ve 69,0 değerlerini aldığı belirlenmiştir. Bu durum, 2016 yllında inşaat sektörü için ortalama \%70'lik bir kapasiteyle çalışmaların yürütüldüğ̈nnü göstermektedir. 
Tablo 6. 2013-2016 yıllarında İTS'ye göre İnșaat Çalışılan Saat Endeksi değișimi [7, 13]

\begin{tabular}{|c|c|c|c|c|c|c|c|}
\hline & & & \multicolumn{4}{|c|}{ Çeyrek } & \multirow{2}{*}{ Yıl ort. } \\
\hline & \multirow{5}{*}{ Toplam } & & I & II & III & IV & \\
\hline \multirow{12}{*}{ İnşaat } & & 2013 & 91,7 & 98,4 & 98,3 & 94,6 & 95,8 \\
\hline & & 2014 & 85,3 & 87,2 & 84,1 & 80,8 & 84,3 \\
\hline & & 2015 & 73,1 & 78,4 & $\mathbf{7 7 , 0}$ & 76,5 & 76,3 \\
\hline & & 2016 & 68,7 & 72,1 & 68,3 & 69,0 & 69,5 \\
\hline & \multirow{5}{*}{ Bina } & 2013 & 94,3 & 99,1 & 97,5 & 94,8 & 96,4 \\
\hline & & 2014 & 88,4 & 90,0 & 86,0 & 83,6 & 87,0 \\
\hline & & 2015 & 77,9 & 82,0 & 78,4 & 78,9 & 79,3 \\
\hline & & 2016 & 72,1 & 73,4 & 66,7 & 66,9 & 69,8 \\
\hline & & 2013 & 85,8 & 97,1 & 100,1 & 94,1 & 94,3 \\
\hline & \multirow{3}{*}{ Bina dışı } & 2014 & 78,4 & 80,8 & 79,8 & 74,7 & 78,4 \\
\hline & & 2015 & 62,4 & 70,4 & 74,0 & 71,1 & 69,5 \\
\hline & & 2016 & 61,0 & 69,2 & 71,9 & 73,8 & 69,0 \\
\hline
\end{tabular}

İnşaat tipleri sınıflaması (İTS)'na göre İnşaat Brüt Ücret-Maaş Endeksi (İBÜME)'nin 20132016 yıllarında çeyrekler bazında değişimi Tablo 7'de verilmiştir. İnşaat Brüt Ücret-Maaş Endeksi'ne ek olarak İTS'ye göre Bina ve Bina Dışı için İnşaat Brüt Ücret-Maaş Endeksleri ve söz konusu endekslerin yıllık ortalama değerleri de verilmektedir. 2010 referans yılında 100 olan endeksin 2016 yılında 130-190 aralığında değerler aldığı, yani 2016 yılında inşaatta brüt ücret ve maaşların 2010 yılına göre en yüksek seviyede gerçekleştiği görülmektedir. Toplam İnşaat Brüt Ücret-Maaş Endeksi, Bina İnşaat Brüt Ücret-Maaş Endeksi ve Bina Dışı İnşaat Brüt Ücret-Maaş Endeksi değerlerinin 2016 y1lı ortalaması sırasıyla $173,6,184,2$ ve 156,3 değerlerini aldığı tespit edilmiştir.

Tablo 7. 2013-2016 y1llarında ITS'ye göre İnşaat Brüt Ücret-Maaş Endeksi değişimi [7, 13]

\begin{tabular}{|c|c|c|c|c|c|c|c|}
\hline \multirow{3}{*}{ Ekonomik faaliyet } & \multirow[b]{2}{*}{ İnşaat tipleri } & \multirow{3}{*}{$\begin{array}{c}\text { Yll } \\
2013\end{array}$} & \multicolumn{4}{|c|}{ Çeyrek } & \multirow{2}{*}{ Yil ort. } \\
\hline & & & I & II & III & IV & \\
\hline & \multirow{4}{*}{ Toplam } & & 132,3 & 144,9 & 150,7 & 149,5 & 144,4 \\
\hline \multirow{11}{*}{ İnşaat } & & 2014 & 142,7 & 149,3 & 150,8 & 149,1 & 148,0 \\
\hline & & 2015 & 141,3 & 152,7 & 158,2 & 160,0 & 153,1 \\
\hline & & 2016 & 163,3 & 177,2 & 174,8 & 179,1 & 173,6 \\
\hline & \multirow{4}{*}{ Bina } & 2013 & 139,4 & 149,9 & 154,5 & 155,2 & 149,8 \\
\hline & & 2014 & 152,8 & 157,4 & 160,0 & 160,3 & 157,6 \\
\hline & & 2015 & 157,0 & 166,1 & 168,9 & 172,4 & 166,1 \\
\hline & & 2016 & 181,9 & 190,9 & 181,0 & 183,1 & 184,2 \\
\hline & \multirow{4}{*}{ Bina dışı } & 2013 & 120,8 & 137,0 & 144,5 & 140,1 & 135,6 \\
\hline & & 2014 & 126,1 & 136,3 & 135,8 & 130,9 & 132,3 \\
\hline & & 2015 & 115,8 & 131,1 & 140,8 & 139,7 & 131,9 \\
\hline & & 2016 & 133,1 & 154,8 & 164,8 & 172,5 & 156,3 \\
\hline
\end{tabular}

2015 ve 2016 yılları için İnşaat İstihdam Endeksi (iïE), İnşaat Çalışılan Saat Endeksi (ICÇSE) ve İnşaat Brüt Ücret-Maaş Endeksi (İBÜME)'nin çeyrekler bazında değişimi Şekil 4'de verilmiştir. İBÜME’nin İİE ve İÇSE’ye göre izafi olarak daha yüksek değerler aldığı görülmektedir. İIEE ve İÇSE esas alındığında söz konusu endekslerin 2015 yılı değerlerinin 2016 y1lı değerlerden daha yüksek seviyede olduğu; İBÜME esas alındığında ise bu durumun tam tersinin gerçekleştiği yani 2016 y1lı endeks değerlerinin 2015 yılı endeks değerlerinden daha yüksek seviyede olduğu görülmektedir. IiIE'nin en düşük değerini 2016 yılı IV. çeyrekte (72,3), en yüksek değerini ise 2015 y1lı II. çeyrekte $(81,9)$ aldığı tespit edilmiştir. Bu durum, 2016 yılında 2015 yılına göre sektördeki istihdam ve çalışma saatlerinin kötüleştiğini, ücretlerde ise iyileşme olduğunu göstermektedir. 


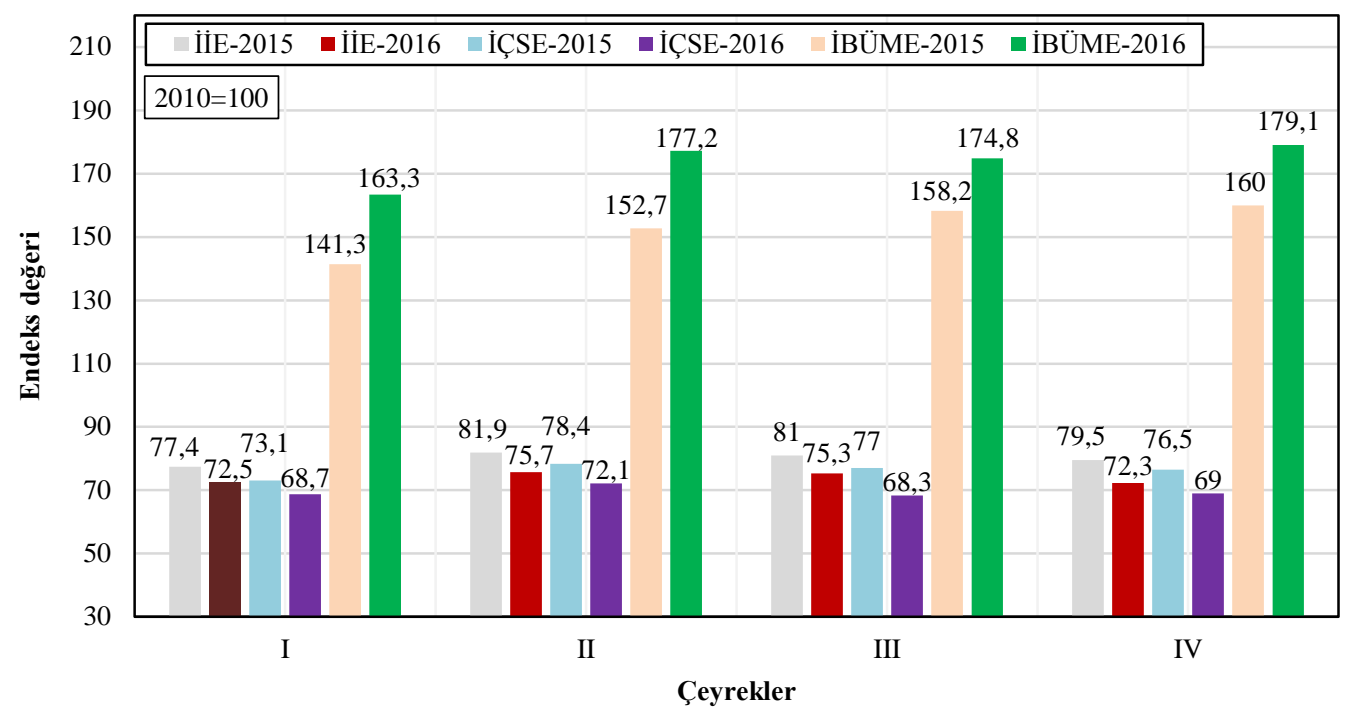

Şekil 4. 2015 ve 2016 yıllarında IIIE, İÇSE ve İBÜME değişimi $[6,13]$

İnşaat İstihdam Endeksi, İnşaat Çalışılan Saat Endeksi ve İnşaat Brüt Ücret-Maaş Endeksi değerlerinin çeyrekler bazında değişimi Mevsim ve Takvim Etkilerinden Arındırılarak da yayınlanmaktadır. Bu kısımda söz konusu endeks değerlerinin değişimi tablolar şeklinde verilmemiş olup tablo değerlerinden elde edilen eğrilerden yararlanılarak değerlendirmeler yapılmıştır.

2013-2016 y1lları için İnşaat İstihdam Endeksi (IIIE)'nin \% değişimleri Şekil 5'de verilmiştir. Söz konusu endeks değişimlerinin hemen hemen bütün dönemlerde negatif değerler aldığı görülmektedir. IïE-TA'da en büyük azalışın 2014 yılı III. çeyreğinde (\%-14,8); en küçük azalışın 2013 yılı I. çeyreğinde (\%-2,9) olduğu; İiE-MTA değerleri esas alındığında en büyük azalışın 2014 yılı III. çeyreğinde (\%-6); tek artışın ise 2014 yllı IV. çeyreğinde (\% 0,2) gerçekleştiği görülmektedir. 2016 yllı son çeyreğinde; ïiE-TA'nın bir önceki yılın aynı çeyreğine göre \% 9,1 azalarak 79,9'dan 73,9'e gerilediği; İïE-MTA'nın ise bir önceki çeyreğe göre \% -3,0 azalarak 72,9'dan 70,7'ye gerilediği görülmüştür. İIE'nin 2015 ve 2016 yıllarının tüm dönemlerinde negatif seyretmesi sektörde istihdam edilenlerin sayısında bir azalma olduğunu ve inşaat sektörünün istihdam açısından beklentileri karşılamadığını göstermektedir.

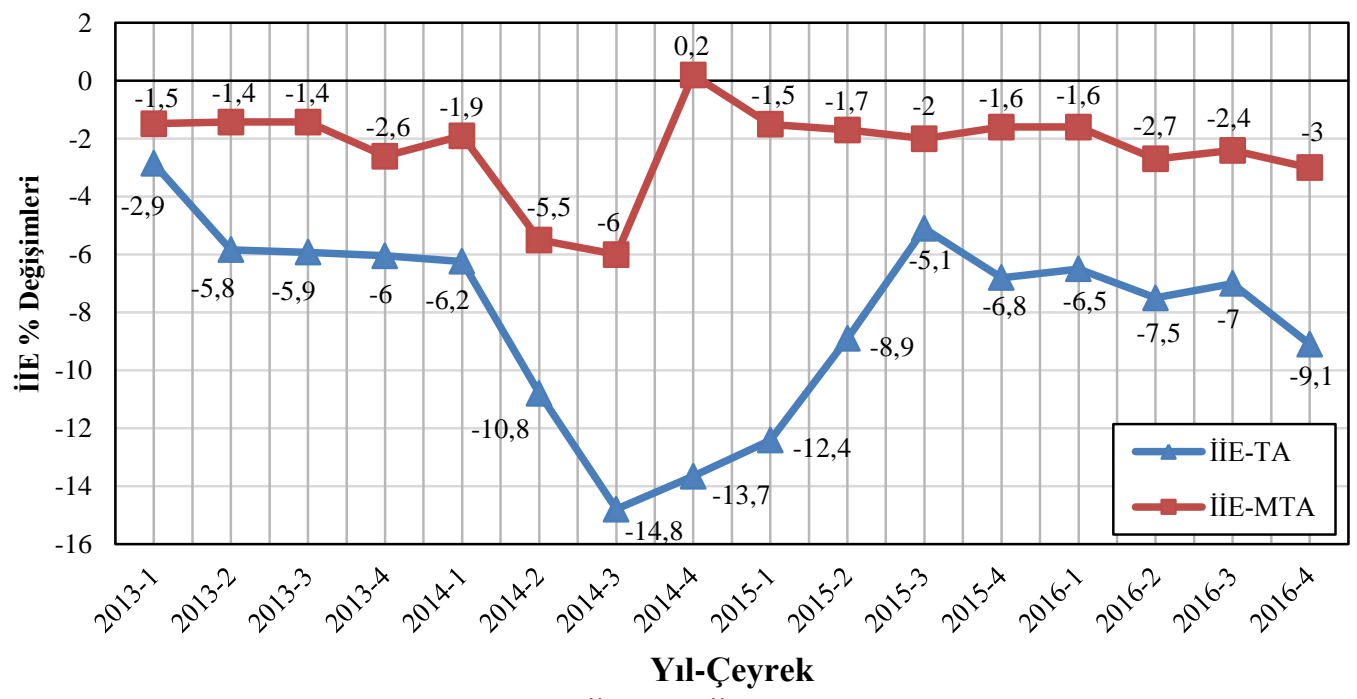

Şekil 5. 2013-2016 yıllarında İ̈E-TA ve İİE-MTA \% değişimleri [7, 13] 
2013-2016 yılları için İnşaat Çalışılan Saat Endeksi (İÇSE)'nin \% değişimleri Şekil 6'da verilmiş̧ir. Şekilden söz konusu endeks değişimlerinin de belirtilen bütün dönemlerde negatif değerler aldığı görülmektedir. İÇSE-TA'da en büyük azalışın 2014 yılı III. ve IV. çeyreklerinde (\%-14,5); en küçük azalışın 2013 yılı I. çeyreğinde (\%-3,5) olduğu; İÇSE-MTA değerleri esas alındığında en büyük azalışın 2016 y1lı III. çeyreğinde (\%-6,1); tek artışın ise 2016 yılı son çeyreğinde (\% 0,4) gerçekleştiği görülmektedir. 2016 yılı IV. çeyreğinde; İÇSE-TA'nın bir önceki yılın aynı çeyreğine göre \% -9,8 azalarak 76,0'dan 68,5'e gerilediği; İÇSE-MTA'nın ise bir önceki çeyreğe göre \% 0,4 artarak 66,6'dan 66,9'a yükseldiği görülmüştür. İÇSE-MTA'nın 2013 yılından itibaren 100 endeks değerinin çok altında seyretmesi ve \% değişimlerinin negatif olması sebebiyle sektördeki çalışma saatlerinin hedeflenen üretim faaliyetleri için yetersiz olduğunu göstermektedir.

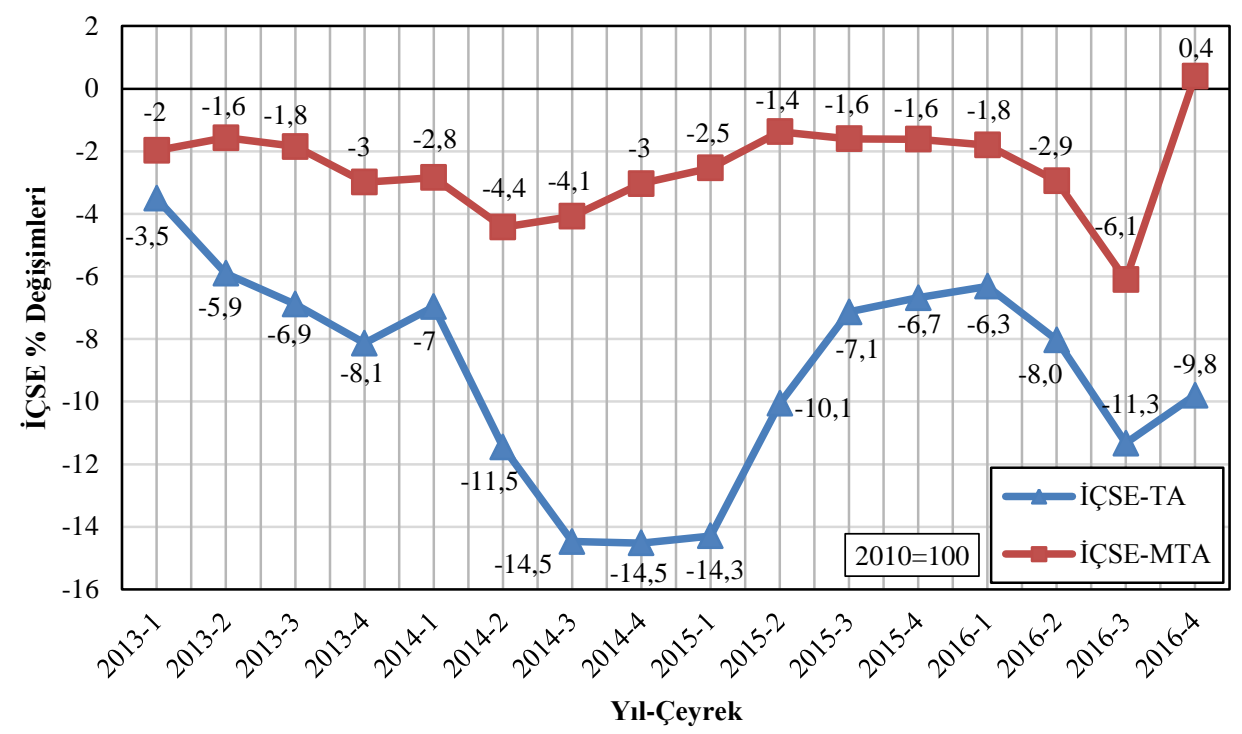

Şekil 6. 2013-2016 yıllarında İÇSE-TA ve İÇSE-MTA \% değişimleri [6, 13]

2013-2016 y1lları için İnşaat Brüt Ücret-Maaş Endeksi (İBÜME)'nin \% değişimleri Şekil 7'de verilmiştir. Şekilden İBÜME-TA'da en büyük artışın 2016 yılı II. çeyreğinde (\% 16,0); en büyük azalışın 2015 yılı I. çeyreğinde (\%-0,9) olduğu; İBÜME-MTA değerleri esas alındığında en büyük artışın 2016 yılı I. çeyreğinde (\% 10,1); en büyük azalışın 2014 yılı II. çeyreğinde (\%-2,1) gerçekleştiği görülmektedir. 2016 yılı IV. çeyreğinde; İBÜME-TA'nın bir önceki yılın aynı çeyreğine göre \% 12,0 artışla 159,2'den 178,3'e yükseldiği; İBÜME-MTA'nın ise bir önceki çeyreğe göre \% 2,3 artarak 171,4'den 175,4'e yükseldiği de şekilden izlenebilmektedir. Bu durum, inşaat sektöründeki brüt ücretmaaşların 2016 yılında bir önceki yıla göre \%11,8 oranında arttığını göstermektedir. 2016 yılı enflasyonunun $\% 8,5$ olduğu düşünüldüğünde; inşaat sektöründeki maaşların enflasyon oranının üzerinde arttırıldı $\breve{1} 1$ ifade edilebilir. 


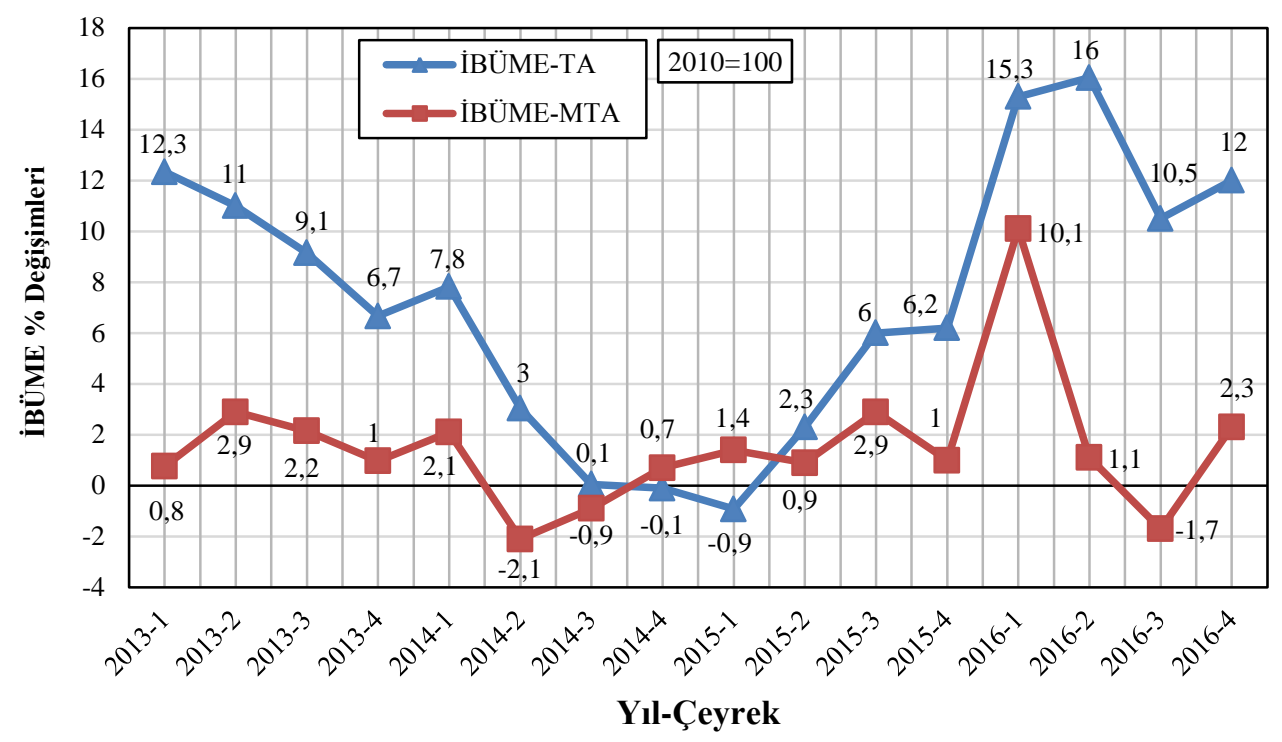

Şekil 7. 2013-2016 yıllarında İBÜME-TA ve İBÜME-MTA \% değişimleri $[6,13]$

\section{3. İnşaat Malzemeleri Sanayi Bileşik Endeksinin Durumu}

İnşaat Malzemeleri Sanayi Bileşik Endeksi; İnşaat Malzemeleri Sanayi Faaliyet Endeksi, İnşaat Malzemeleri Sanayi Güven Endeksi ve İnşaat Malzemeleri Sanayi Beklenti Endeksi gibi ana alt endekslerin birleşiminden elde edilmektedir. İnşaat Malzemeleri Sanayi (IMS) Bileşik Endeksi'nin 2013 yılı Eylül ayı ile 2016 yılı Kasım ayı arasında aylar bazında değiş̧imi Şekil 8'de verilmiştir. İMS Bileşik Endeksi'nin 2016 yılı Haziran ayından itibaren bir gerileme trendinde olduğu ve 2016 yılı Kasım ayında endeksin ölçülmeye başlandığı aydan bu yana en düşük olduğu $(92,8)$, söz konusu endeksin 2014 yılı Mayıs ayında ise en yüksek $(106,8)$ seviyede olduğu görülmektedir. 2016 yılı Ekim ayında 94,6 değerinde olan IMMS Bileşik Endeksi 2016 yılı Kasım ayında bir önceki aya göre \% 1,9 azalarak 92,8'e düşmüştür. Bu durum, mevsimin olumsuz etkisi ve Kasım ayında yaşanan iç ve dış gelişmelerden (küresel yeni mali koşullar, Türk Lirasındaki değer kaybı vb.) kaynaklanmaktadır.

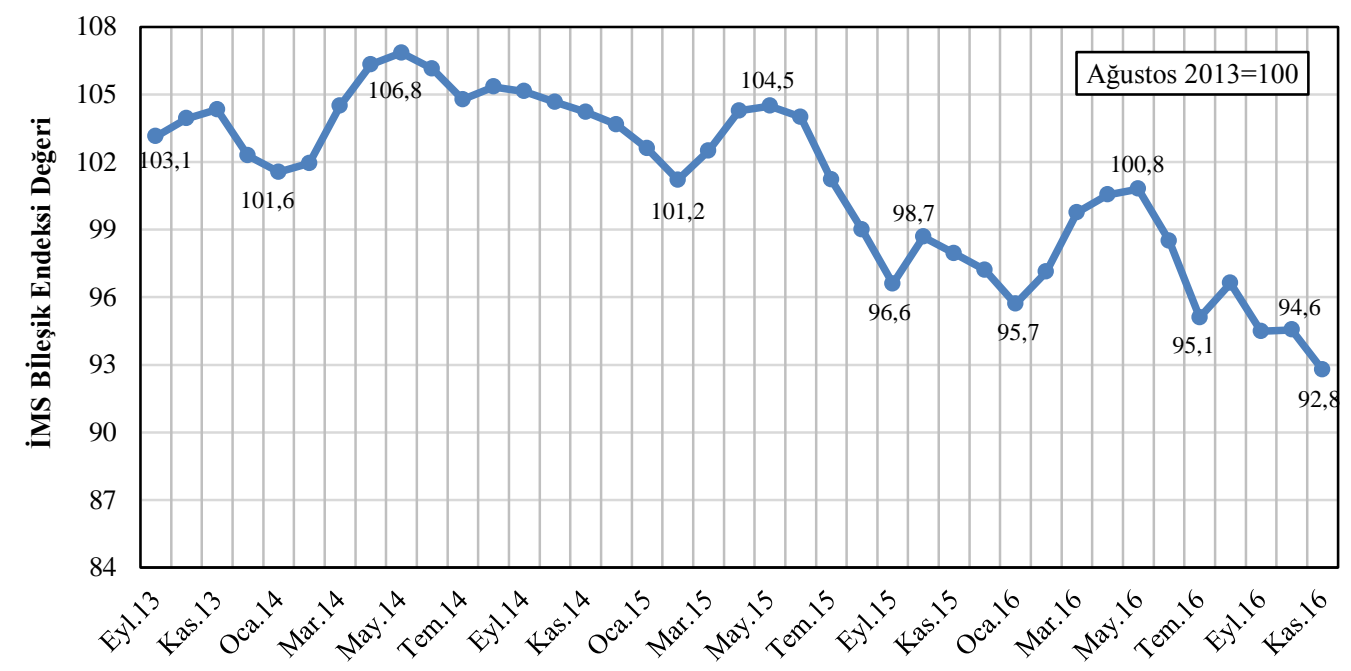

Şekil 8. Eylül 2013-Kasım 2016 dönemlerinde İMS Bileşik Endeks değişimi [9] 
İnşaat Malzemeleri Sanayi (IMS) Faaliyet Endeksi'nin 2013 yılı Eylül ayı ile 2016 yılı Kasım ayı arasında aylar bazında değişimi Şekil 9'da verilmiştir. Şekilden IMMS Faaliyet Endeksi'nin endeksin ölçülmeye başlandığı ayda (2013 Eylül) en düşük (104,6); 2016 yılı Mayıs ayında ise en yüksek $(132,5)$ seviyede olduğu görülmektedir. 2016 yılı Ekim ayında 125,9 değerinde olan İMS Faaliyet Endeksi'nin 2016 yılı Kasım ayında \% 0,08 azalarak 125,8'e gerilemiş olduğu görülmektedir. Bu durum, darbe girişimi sonrası inşaat faaliyetlerinin durağan ve zayıf seyretmeye devam ettiği anlamına gelmektedir.

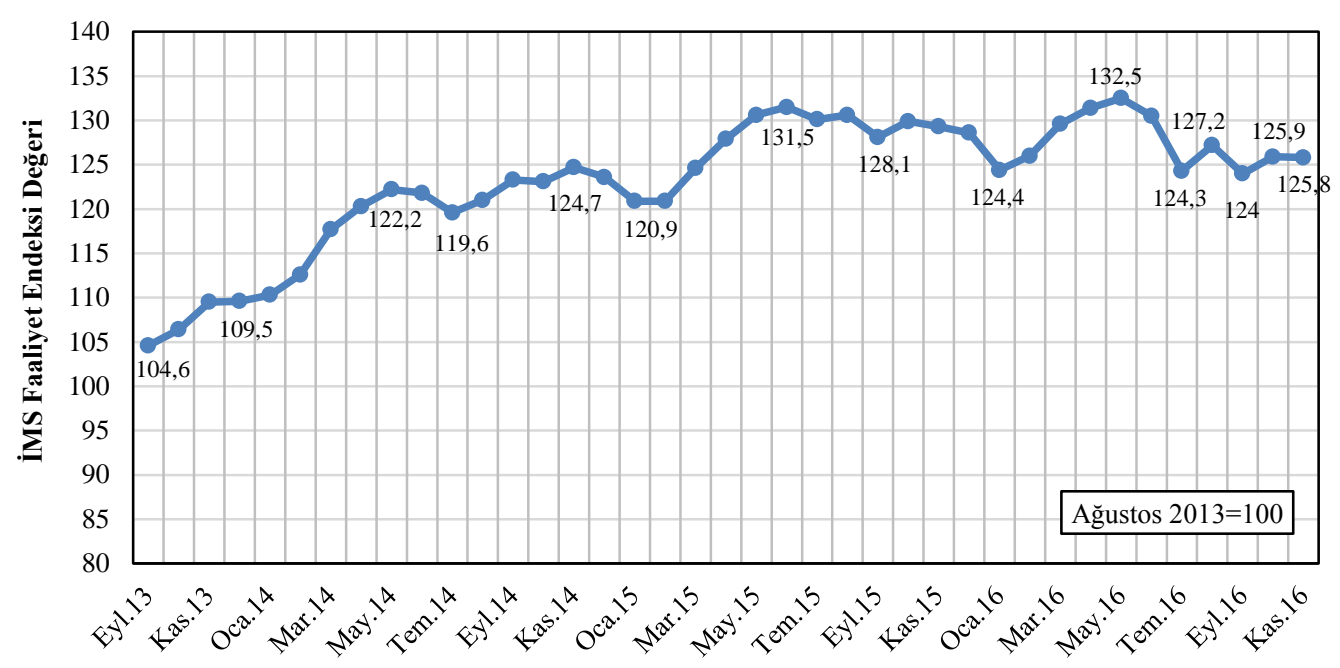

Şekil 9. Eylül 2013-Kasım 2016 dönemlerinde İMS Faaliyet Endeksi değişimi [9]

İnşaat Malzemeleri Sanayi (IMS) Güven Endeksi’nin 2013 yılı Eylül ayı ile 2016 y1lı Kasım ayı arasında aylar bazında değişimi Şekil 10'da verilmiştir. Şekilden İMS Güven Endeksi’nin, söz konusu endeksin ölçülmeye başlandığı ayda (2013 Eylül) en yüksek (102) seviyede olduğu; ilerleyen aylarda ise genel olarak azalış trendi gösterdiği ve 2016 yılı Kasım ayında en düşük seviyeye $(65,5)$ gerilediği görülmektedir. Bu durum, ekonomide alınan yoğun önlemlere ve desteklere rağmen ekonomiye ve sektörlere yönelik güvende henüz iyileşme olmadığını göstermektedir.

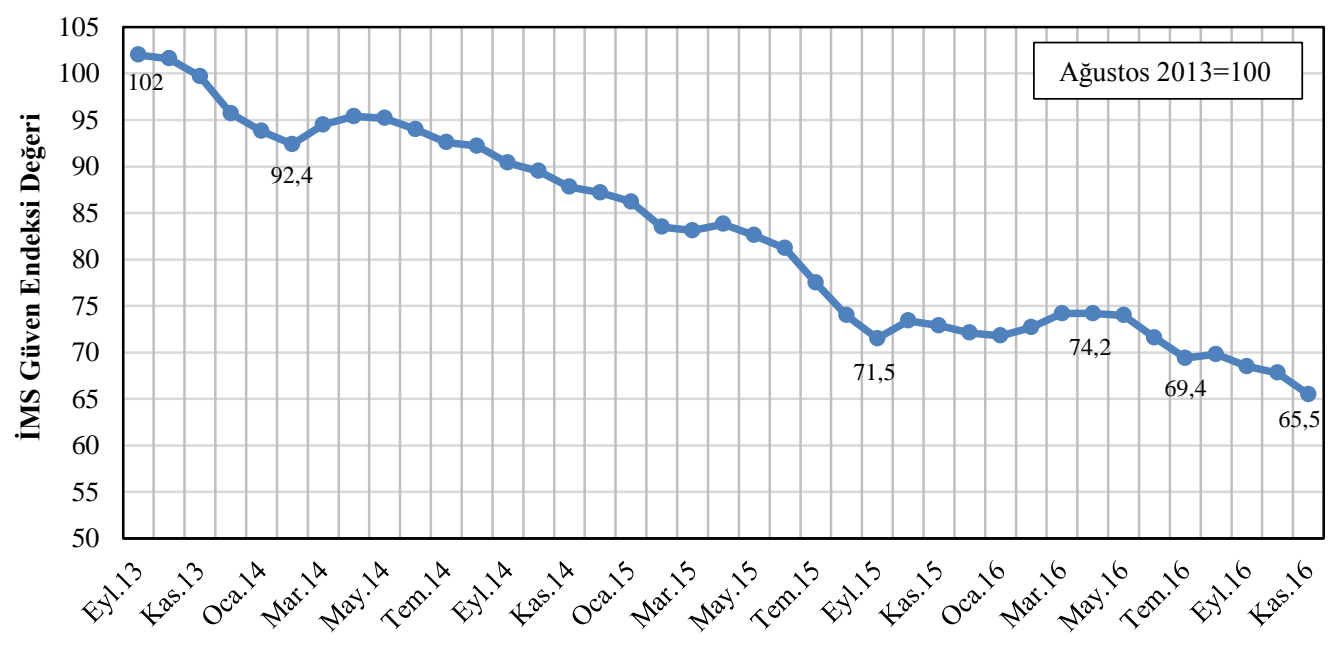

Şekil 10. Eylül 2013-Kasım 2016 dönemlerinde İMS Güven Endeksi değişsimi [9] 
İnşaat Malzemeleri Sanayi (IMS) Beklenti Endeksi'nin 2013 yılı Eylül ayı ile 2016 yılı Kasım ayı arasında aylar bazında değişimi Şekil 11'de verilmiştir. Şekilden IMSS Beklenti Endeksi'nin endeksin ölçülmeye başlandığı aylarda en yüksek seviyede olduğu (Kasım 2013'te 102,9); ilerleyen aylarda ise genel olarak azalış trendi gösterdiği ve 2016 yılı Kasım ayında en düşük seviyeye $(85,7)$ gerilediği görülmektedir. Faaliyetlerde görülen durağanlık ve güven kaybının sürmesi nedeniyle beklentiler de olumsuz etkilenmekte olup güven ve beklentilerde iyileşme için yeni adımlara ihtiyaç duyulmaktadır.

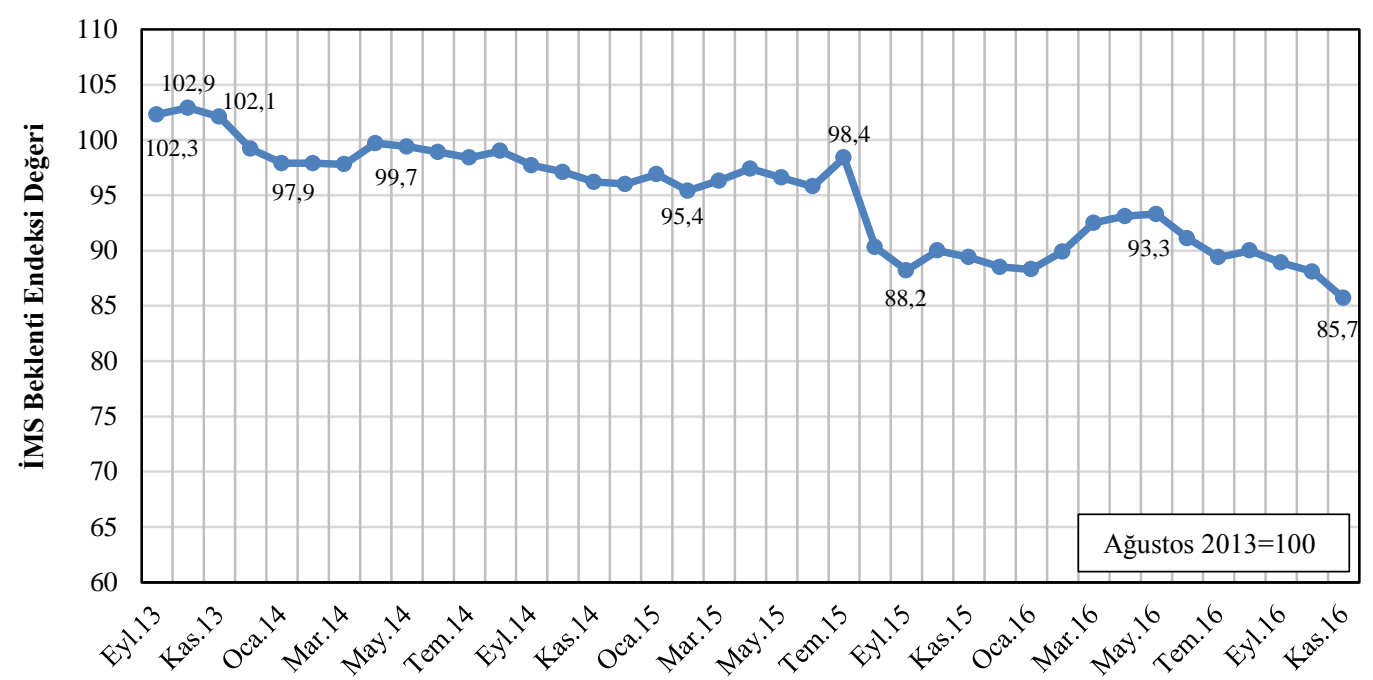

Şekil 11. Eylül 2013-Kasım 2016 dönemlerinde İMS Beklenti Endeksi değişimi [9]

\section{Tartışma ve Sonuç}

Ülkemizde inşaat sektörünün durumunu tespit etmek amacıyla çeşitli endeksler kullanılmaktadır. Bu endeksler; İnşaat Ciro Endeksi, İnşaat Üretim Endeksi, İnşaat İstihdam Endeksi, İnşaat Çalışılan Saat Endeksi, İnşaat Brüt Ücret-Maaş Endeksi ve İnşaat Malzemeleri Sanayi (İMS) Faaliyet Endeksi, İMS Güven Endeksi ve İMS Beklenti Endeksi şeklinde sıralanmaktadır. Bu endekslerle ilgili elde edilen sonuçlar aşağıda maddeler halinde verilmiştir:

- 2016 yılında 2015 y1lına göre İnşaat Ciro Endeksi (İCE) ve İnşaat Üretim Endeksi (İÜE) ve İnşaat Brüt Ücret-Maaş Endeksi (İBÜME) artmıştır. Bu durum, ekonomik büyümeyle paralel olarak 2015'e göre 2016 yılında inşaat sektöründeki cironun, üretim faaliyetlerinin ve maaşların arttığını göstermektedir. Ayrıca, 2016 yllında İnşaat Ciro Endeksi (ICE) ve İnşaat Üretim Endeksi (iÜE) değerlerindeki artış, inşaat sektöründeki ciro ve üretim faaliyetlerinin sırasıyla $\% 12$ ve $\% 3,2$ oranında artmasıyla sonuçlanmıştır.

- 2016 y1lında 2015 yılına göre İnşaat Çalışılan Saat Endeksi (ICÇSE) ve İnşaat İstihdam Endeksi (iiE) azalmış olup bu durum sektördeki istihdamın ve çalışma saatlerinin kötüleştiğini göstermektedir.

- Yürütülen çalışmada, İnşaat İstihdam Endeksi (IïE)'nin 2010 yılından itibaren her yıl giderek azaldığı tespit edilmiştir. 2016 yılı üçüncü çeyreğinde ise İnşaat İstihdam Endeksi'nin darbe teşebbüsü etkisiyle ciddi oranda azaldığı ve bu durumun sektördeki istihdamı olumsuz etkilediği sonucuna varılmıştır. Ayrıca, İnşaat İstihdam Endeksi (ïIE)'ndeki ani düşüşler, İnşaat Çalışılan Saat Endeksi (IÇSE)'nin de azalmasına sebep olmaktadır. 
- İnşaat Malzemeleri Sanayi (İMS) Bileşik Endeksi, 2016 yılı Haziran ayından itibaren azaldığı görülmüştür. Bu durumun; mevsimin olumsuz etkisi, 2016 yılı Kasım ayında yaşanan küresel yeni mali koşullar, Türk Lirasındaki değer kaybı ve döviz artışından kaynaklandığı düşünülmektedir.

- İnşaat Malzemeleri Sanayi (IMS) Faaliyet Endeksi 2016 y1lı süresince yaklaşık 125-130 seviyesindedir. Bu endeks, Yurtiçi Satış Endeksi, Üretim Endeksi, İhracat Endeksi, Ciro Endeksi, Tahsilat Hızı Endeksi, Yurtdışı Satış Fiyatları Endeksi gibi alt endekslerden oluştuğundan 2016 yılında inşaat sektörünün hem ciro hem de satış bakımından iyi durumda olduğunu göstermektedir.

- İnşaat Malzemeleri Sanayi (IMS) Güven Endeksi değerinin 2016 yılı Temmuz ayı itibariyle düşüş sürecine girdiği belirlenmiştir. Bu durum, ekonomide alınan yoğun tedbirlere rağmen dövizdeki yükseliş ve TL'deki değer kaybı sebebiyle inşaat sektörüne yönelik güvende henüz bir iyileşme olmadığı tespit edilmiştir.

- İnşaat Malzemeleri Sanayi (İMS) Beklenti Endeksi değeri 2016 yılının son aylarında en düşük seviye olan 85,7'ye düşmüştür. İnşaat sektöründeki güven kaybı sebebiyle beklentilerin oldukça düşük olduğu görülmüş olup beklentilerde iyileşme için yeni adımlara ihtiyaç duyulmaktadır.

Sonuç olarak; ülkemizdeki inşaat sektörünün 2016 yılında hem üretim hacmi hem de ciro bakımından büyümesine rağmen sektöre olan güven ve beklentinin oldukça düşük seviyede olduğu belirlenmiştir. $\mathrm{Bu}$ durumun düzeltilmesi için öncelikle faiz oranlarının düşürülmesi ve döviz kurunun düşük seviyelerde tutulması gerekmektedir.

\section{Kaynaklar}

[1] Koç, E., "Osmaniye'nin Sosyoekonomik ve Kültürel Yapısı”, Adana Nobel Yayınevi, Osmaniye, Türkiye, 2008.

[2] Karluk, S.R., "Türkiye Ekonomisi, Tarihsel Gelişim, Yapısal ve Sosyal Değişim”, Beta Basım, İstanbul, Türkiye, 2002.

[3] Mevsim ve Takvim Etkilerinden Arındırılmış İnşat İşgücü Girdi, Ciro ve Üretim Endeksleri 2016, http://www.tuik.gov.tr/indir/m_t_metaveri/insaat_mv.pdf, erişim tarihi: 02.03.2017.

[4] Y1llk Ekonomik Rapor 2014, https://www.maliye.gov.tr/Documents/Y\%C4\%B111\%C4\%B1k\%20Ekonomik\%20Rapor\%2020 14.pdf, erişim tarihi: 03.03.2017.

[5] Yillık Ekonomik Rapor 2015, https://www.maliye.gov.tr/Documents/Y\%C4\%B111\%C4\%B1k\%20Ekonomik\%20Rapor\%2020 15.pdf, erişim tarihi: 03.03.2017.

[6] İnşaat Ciro ve Üretim Endeksi, http://www.tuik.gov.tr/PreTablo.do?alt_id=1022, erişim tarihi: 02.03. 2017.

[7] İnşaat İşgücü Girdi Endeksleri, http://www.tuik.gov.tr/PreTablo.do?alt_id=1023, erişim tarihi: 09.03.2017.

[8] Türkiye İMSAD İnşaat Malzemeleri Sanayi Bileşik Endeksi Genel Bilgileri, http://imsad.org/insaat-malzemeleri-sanayi-endeksleri/, erişim tarihi: 10.03.2017. 
Koç E., Kaya K., Şenel M.C.

[9] Türkiye İMSAD İnşaat Malzemeleri Sanayi Bileşik Endeksi Basın Bülteni, http://www.imsad.org/Uploads/Files/T\%C3\%BCrkiye_\%C4\%B0MSAD_Endeks_BASIN_NOT U_kasim2016.pdf, erişim tarihi: 10.03.2017.

[10] Türkiye İMSAD İnşaat Malzemeleri Sanayi Bileşik Endeks Sonuç Raporu, http://imsad.org/Uploads/Files/imsad_endeks_sayi24_kasim_2016.pdf, erişim tarihi: 10.03.2017.

[11] İnşaat Ciro ve Üretim Endeksi, http://www.tuik.gov.tr/PreHaberBultenleri.do?id=24716, erişim tarihi: 01.11.2017.

[12] İnşaat Ciro ve Üretim Endeksi, http://www.tuik.gov.tr/PreHaberBultenleri.do?id=24718, erişim tarihi: 01.11.2017.

[13] İnşaat Malzemeleri Sanayi Endeksi http://imsad.org/Uploads/Turkiye_IMSAD_SanayiEndeksleri_\%20EYLUL2017_SAYI_34.pdf, erişim tarihi:01.11.2017. 